\title{
Pärimuslikud kohamääratlused ja liikuvate ohuallikate kaardistamine usundilistes juttudes
}

\begin{abstract}
Reet Hiiemäe
Teesid: Artiklis vaadeldakse pärimuslikel kohamääratlustel põhinevate mentaalsete ohukaartide vahendamist usundilistes juttudes. Uudne on keskendumine narratiivsetele lokaliseerimisilmingutele seoses liikuvate (seega mitte ühe kindla kohaga seotud) ohuallikatega. Näidatakse, et mentaalsete ohukaartide kujunemise protsess on sarnane nii vanemate muistendite (näiteks katkumuistendid) kui ka tänapäevaste meediamõjuliste uskumusnarratiivide (näiteks ohtlikest kurjategijatest rääkivad jutud) puhul. Samuti käsitletakse selliste ohukaartide tähtsust info selektiivsel kogumisel ja mäletamisel ning sellest lähtuva edasijutustamise ja käitumise tingijana. Autor jõuab järeldusele, et lisaks pragmaatilistele tekkepõhjustele (abivahend ohutuks liikumiseks ruumis) kannavad narratiivsed ohukaardid endas subjektiivset toimetulekutunnet toetavat julgestusfunktsiooni.
\end{abstract}

Märksõnad: kognitiivne kaardistamine, kohad, meediamõjuline jutustamine, narratiivne lokaliseerimine, usundilised jutud

Rahvajuttudes kohtab arvukalt nii väljamõeldud (nt muinasjuttudes) kui ka reaalselt olemasolevaid kohti (nt usundilistes juttudes). Nagu muudel rahvastel, on ka eesti usundilises jutupärimuses palju geograafiliselt olemasolevate kohtadega seostuvaid kohamääratlusi, näiteks umbes $90 \%$ katkujuttudes mainitakse konkreetseid kohti. Ühelt poolt on nende kasutamine ootuspärane ja omane eriti muistendižanrile, sest see lisab narratiivile usutavust ja konkreetsust, kuid teisalt on huvipakkuvad veel mõned kohanimede mainimise ajendid (nt kognitiivse kaardistamise taotlus). Järgnevas püüan leida vastust küsimusele, kuivõrd saab rääkida usundilistes juttudes kasutatavate kohamääratluste puhul nende teatavast mentaalsest julgestusfunktsioonist. Aitavad need ju katkuvaimust, kummitustest, eksitajatest jm uskumusolenditest rääkivates juttudes ootamatult ilmuvat ohtu lokaliseerida. Võib täheldada, et kohamääratluste kaudu toimub neis tekstides maastiku kognitiivne kaardistamine vastandite ohtlik - ohutu alusel ja sellest tulenevalt asjakohase käitumise valik. 
Usundilistes juttudes esinevad lokaliseeritult enamasti sellised ohuallikad, mis on kindlalt piiritletud territooriumiga (nt metsavaim ja eksitaja figureerivad metsas, surnute vaimud kalmistul või inimese surmasaamise kohas). Käesolevas artiklis keskendun just liikuvate ohuallikate kaardistamispüüetele usundilistes juttudes, kuna seda aspekti käsitlevaid uurimusi pole mulle teadaolevalt varem ilmunud.

Näiteks ei olnud katkuhaigust selle järkjärgulise edasiliikumise tõttu võimalik seostada ühe konkreetse paigaga, küll aga mingi liikumissuunaga, seega on ootuspärane, et narratiivselt püüti kaardistada katkuvaimu kui selle haiguse personifikatsiooni liikumisteed. Esmalt vaatlengi mentaalse kaardistamise protsesse katkupärimuse näitel, seejärel käsitlen paralleele tänapäevaste usundinähtustega, nagu seda on nelipühilastel spirituaalne kaardistamine, mille abil on püütud tuvastada kohti maastikul, kus inimesi varitsevad deemonid (vrd nt Howard 2009: 167), ning ohtlike kurjategijate liikumistrajektoori piiritlemine nende narratiivse sidumise kaudu kindlate sõlmpunktidega maastikul. Seega oletan, et lisaks paiksetele ohuallikatele on püütud kaardistada ka liikuvaid ohuallikaid ning see protsess on sarnane nii vanemate muistendite kui ka tänapäevaste meediamõjuliste uskumusnarratiivide puhul.

Katkupärimuse osas lähtun usundilisest materjalist, mis leidub siinkirjutaja koostatud ja üle 1500 pärimusteksti sisaldavas teoses Eesti katkupärimus (1997). Uuemate lokaliseerimisnähtuste uurimisel on aluseks viimase paari aasta ajaleheartiklid, internetikommentaariumide ja sotsiaalmeedia postitused ning umbes kakskümmend üksikisikutega tehtud intervjuud, nelipühilaste praktiseeritud spirituaalse kaardistamise osas vastavad veebilehed ja uurimused (viimastest vt nt Holvast 2009; Howard 2009).

\section{Mentaalsed maakaardid teoorias ja praktikas}

Kuigi kognitiivsete kaartide temaatika kerkis seoses Eduard Tolmani rottide ruumikäitumist vaatleva uurimusega üles juba pärast 1948. aastat ja tosin aastat hiljem lisandus Kevin Lynchi (1960) murranguline teos kognitiivsete kaartide kasutamisest linnaruumi tajumisel, on kognitiivsed kaardid psühholoogia, semiootika, inimgeograafia ja mõnevõrra ka folkloristika valdkonna töödes (nt Ryden 1993; Arukask 2007) kõlapinda leidnud eelkõige alates 1970. aastatest, kusjuures termini kognitiivne kaardistamine tähendusväli on uurimuste lõikes mõnevõrra erinev. Käesoleva uurimuse konteksti sobiv baasdefinitsioon pärineb tuntud inimgeograafidelt Roger M. Downsilt ja David Stealt: "Kognitiivne kaardistamine on protsess, mis koosneb reast psühholoogilistest transformatsioonidest, mille abil inimene võtab vastu, kodeerib, salvestab, mee- 
nutab ja dekodeerib teavet oma igapäevases ruumilises ümbruses kogetavate nähtuste suhteliste asukohtade ja omaduste kohta" (Downs \& Stea 2011: 312). Jutu-uurimises mõeldakse mentaalse või kognitiivse kaardistamise all näiteks viise, kuidas jutustaja kasutab mentaalset kaarti mnemotehnilise vahendina või kuulaja loob oma mõtetes kaardi jutus mainitud kohtadest, et räägitust paremini aru saada (nt Labrie 1999; Herman 2000; Herman 2003). Enamasti lähtuvad need käsitlused seega konkreetsetest jutustajatest või kuulajatest.

Minu huvikeskmes on esmalt mütoloogilise olendi - katkuvaimu - liikumise kaardiline kujutamine katkujuttudes, ning tehtud järeldused puudutavad sellise kaardistamise funktsioone mentaalse enesekaitse mehhanismina. Seega saab siin rääkida 'igapäevasest ruumilisest ümbrusest', mille toovad oma eelmainitud definitsioonis välja Downs ja Stea, küll teatavate mööndustega, kuna jutt on kohtadest, mis on pärimusekandjate lähiümbruses reaalselt olemas, kuid need on usundilistes juttudes esitatud lähtuvalt mütoloogilisest mõõtmest, see tähendab üleloomuliku olendi tegevuse toimumiskontekstina. Seega on need kohad kultuuriliselt/mütoloogiliselt determineeritud, ehk nagu märgib maastike kohta üldisemalt ka Barbara Bender, "[need on] inimeste loodud nende endi kogemuse ja maailmaga suhestumise kaudu. Seega on need kestvas kujundamise ja ümberkujundamise protsessis" (Bender 2002: S103).

Mitmed autorid on järeldanud, et usundilisi jutte ja üldse rahvajutte säilitatakse mälus lisaks tekstile ka pildilisel kujul (nt Stanonik 1993: 158; Metsvahi 2007: 33), muuhulgas teatavate geosemantiliste kujutistena (nt Tangherlini 2010). Emily Lyle juurutab oma töös Merlin Donaldile tuginedes termini väline mäluala (External Memory Field), mille all ta mõtleb "bioloogilisest mälust väljapoole jäävat kognitiivset töötsooni”, sedastades ühtlasi, et selline välise ja sisemise mälu koostöö sai tõenäoliselt olla kõige täielikum just kirjutamise-eelsel ajastul (Lyle 1993: 64). Seega võib Lyle’ile tuginedes väita, et väline mäluala hõlmab ka reaalselt olemasolevaid kohti, mille mentaalsete (ehk siis sisemiste) representatsioonide baasil koostatakse rahvajuttudes ohukohtade mõttelised kaardid. Nendes kaartides kajastub ajastuomane kultuuriline kontekst, näiteks maastikuüksuste administratiivsete piiridega arvestamisena. Katkujuttudes kujutatakse katkuvaimu liikumist valdavalt ühe valla või kihelkonna piires, seega hõlmab see enamasti mõnikümmend kilomeetrit ega ületa areaali, mille raames tollane (st kuni 20. sajandi algupoolel elanud) suhteliselt paikse eluviisiga inimene valdavalt ise liikus. Tänapäeval on inimesed liikuvamad, ent narratiivsed lokaliseerimismudelid lähtuvad endist viisi lähiümbrusest. Nüüdisaegsed mentaalsed ohukaardid võivad vahel hõlmata ka tervet Eestit ja kaugemaidki paiku, aga nende mõju käitumisele paistab seostuvat ikka esmajoones mõnekümne kilomeetri raadiusega (ehk siis umbes vallasuuruse maastikuüksusega). Osalt inimese kognitiivse vastuvõtlikkuse 
ja meeldejätmisvõime piiratuse tõttu, eelkõige aga huvifookuse keskendumise tõttu lähiümbrusele on narratiivides loetletud kohtade hulk piiratud. Näiteks ei ole üheski katkumuistendis loetletud üle kümne koha, tavaliselt piirdutakse kuni viie kohaga jutu kohta.

Mainimist väärib, et selline mälus säilitatav kognitiivne ohukaart pole kindlasti päris samasugune nagu tänapäevastest teedeatlastest tuntud kaardid, mis meile sõna maakaart kuuldes ehk esimesena silme ette tulevad (viimased on põhimõtteliselt samuti teatavaid valikulisi kultuuri- ja ajastuomaseid leppemärke ja sümboleid kasutavad maastiku rekonstruktsioonid). Katkujuttude tekkimise ja hiljem ka kogumise ajal polnud maakaardid veel tavainimeste kodudes kuigi laialdaselt kasutusel ja nii või teisiti pole eelduspärane, et ühe üksikisiku mentaalne orienteerumisskeem saaks kattuda mõne sellise üldkaardiga. Kognitiivne maakaart sisaldab lisaks valikulisele maastikulisele infole alati ka tundetasandi kvaliteete ja tähendusi, esindades inimese subjektiivset maailmanägemust. Ent seda huvitavam on arutleda, kuidas kujutasid inimesed ruumisuhteid füüsilise maakaardi eeskujule tuginemata.

Mitmed psühholoogia valdkonna uurijad on rõhutanud, et mentaalsete maakaartide loomisel mängib olulist rolli inimese sugu, vanus, sotsiaalsed rollid, isiksus jms või et inimese võime luua kognitiivseid kaarte on küll universaalne, kuid konkreetsed väljundid siiski isikuti erinevad (nt Wilde 2007: 121). Arhiveeritud muistenditekstide puhul on võimalik rekonstrueerida ainult teatav homogeniseeritud versioon, milles individuaalsed ja soolised erinevused kuigivõrd ei ilmne. Siinkirjutaja arvates võib kognitiivsete kaartide puhul rääkida mitmekihilisusest: osa kihte on individuaalsed, teised mingi rühma piires jagatavad. Nende kihtide kogusumma moodustab iga üksikisiku puhul unikaalse terviku. Muistenditekstide baasil rekonstrueeritud mentaalseid ohukaarte saab seega käsitada ühe kihina selles kaardimassiivis.

Kui mõnedki kognitiivse kaardistamise teoreetikud on rõhutanud, et ruumilise teabe vastuvõtmisel ja selle põhjal kognitiivsete kaartide koostamisel on oma roll tervel real sensoorsetel modaalsustel (nt nägemise, kuulmise, haistmise, kompamise kaudu saadav teave) (Downs \& Stea 2011: 316), siis sellistest minevikunähtustest nagu katk (viimane katkupuhang oli Eestis 18. sajandi alguses) räägitavate juttude puhul saab nende kogumisaega (alates 19. sajandi lõpust) arvesse võttes rääkida vaid kujutluslikust lähenemisest. Jutu kuulajad ja edasirääkijad võisid üksnes kujutleda, mida juttudes nimetatud kohtade elanikud katkuaegadel tundsid, ja nende kujutlustega seostuvalt luua omaenda mentaalseid ohukaarte.

Tänapäevaste lokaliseerimisfenomenide käsitlemisel on vähemalt memoraadina räägitud juttude puhul individuaalne sensoorne aspekt küll esindatud, kuigi individuaalsetel mentaalsetel ohukaartidel leidub väga palju ka selliseid 
kohti, kus nad pole ise kunagi viibinud, seega saab siin rääkida samuti põhinemisest - sageli meediamõjulisel - imaginatsioonil. Seega lisandub nüüdiajal biograafilisele ja pärimuslikule mälule ka meediamälu komponent. Igal juhul nõustun nende uurjatega, kes väidavad, et kognitiivsest kaardist saab siin "üldise ruumilise probleemide lahendamise võttestiku oluline komponent" (Golledge \& Stimson 1997: 237).

Katkujuttudes esinevate kohamääratluste põhjal rekonstrueerin rea skeeme, mille aluskaardina olen kasutanud tänapäevaseid maakaarte, kuna esitamine suurema geograafilise ala taustal võimaldab paremini näitlikustada mentaalsete maakaartide sõlmpunkte tegelike geograafiliste ruumisuhete valguses, liiatigi poleks toonaste jutustajate individuaalseid mentaalseid kaarte füüsilisel kujul nii või teisiti võimalik hankida.

Usundiliste juttude puhul laiemalt saame rääkida muutuvatest ja püsivatest kohaüksustest mentaalsetel ohukaartidel ning nende kohatisest kombineerumisest. Näiteks läbib katkuvaim ehk kohtamuutev usundiline ohuallikas oma liikumisteekonnal mõnel juhul surnuaia (maastikul püsivalt paiknev usundiline ohuallikas). Tänapäeval seostub surnuaed mitmes narratiivis kardetud kurjategijate ja maniakkide tegutsemispaigaga (näiteks kasvõi juba paarkümmend aastat eelkõige laste juturepertuaari kuuluv populaarne õuduslugu surnusööjast naisest, kes laseb end taksoga kolmele erinevale kalmistule sõidutada). Seda kujutlust on toetanud meedias rohkelt kajastatud juhtumid, näiteks 2012. aastal laineid löönud kalmistumõrvariks tituleeritud noore kurjategija Aarne Kuusalu lugu (nt Haravee 2013) või lood kalmistul tegutsenud kotivarastest (nt LL 2011).

Seega valivad inimesed oma mentaalsele ohukaardile reaalselt olemasolevad kohad, kuid neile omistatud tähendus muutub ajas ja kultuuriruumiti, sõltudes jutustamistraditsioonist; jutustamisviisid omakorda sõltuvad inimkogemusest ja sellest, kuidas neid antud kultuurikontekstis verbaliseeritakse. Kohad on siin käsitletavad ohtude referentspunktidena või gradatsioonibaasina - mida rohkem rahvas neist võimalike ohtude kontekstis räägib, seda veenmisjõulisemaks need ohuallikana muutuvad (kohtadest jutustamise intensiivsuse ja sootsiumis valitsevate hirmude tihedast seosest on kirjutanud ka Matei et al. 2001).

Sageli on narratiivsetel ohukaartidel näidatud marsruutidel algus- ja lõpppunkt, nende vahele mahub rohkemal või vähemal määral samaväärtuslikke sõlmpunkte, mõnikord aga moodustavad marsruudid keerulisemaid ja haralisemaid võrgustikke. Samuti tajutakse keskmeid ja perifeeriaid ning piire erineva kvaliteediga alade (ohtlik-mitteohtlik, ohu seisukohalt aktuaalne-mitteaktuaalne jne) vahel. Kujutatud piirid võivad olla teravad või hägusad, rohkem või vähem muutumisaltid. Sarnasest kognitiivsete ruumisuhete põhimõttest on 
lähtutud tänapäevases linnaruumis infosüsteemide ja hoonestuse planeerimisel (vrd Jarz 1997: 94), Eesti puhul on räägitud näiteks vajadusest "kodustada" sobivate planeerimisvõtete abil kriminaalse kuulsusega Kopli asum Tallinnas.

\section{Katkuvaimu liikumistee narratiivne fikseerimine}

Katku puhul ei teatud haiguse tegelikke põhjuseid ega seda, kui kaugele haiguspuhang ulatub ja millal lakkab. Sestap andis mütoloogiline mõtlemine talle esmalt vormi, mis võimaldas kõikjal varitseva nähtamatu nakkuse koondamise visuaalselt nähtava haigusvaimu kujusse. Personifitseeritud katkuvaimu sidumine konkreetsete kohtadega andis haigusohule maastikulised pidepunktid, muutes haiguse liikumise teatud mõttes ettearvatavaks. Katkujuttudes on põhifookus katkuvaimu tegevusel, neis kujutatud kohad on taustaplaanina juttude lahutamatu osa, olles dünaamiliselt seotud jutus kirjeldatud tegevusega.

Mõningates katkujuttudes kasutatakse ruumilise teadmuse edastamiseks alliteratsioonil ja lauserütmil põhinevaid stereotüüpseid vormeleid, nagu "Päinurme, Pätsavere, Suurluige, Lustivere" või "Otsale onule, Tikule tädile”. Selliseid vormeleid ja nendest lähtuvaid kaardilisi visualisatsioone sisaldavad narratiivid on säilinud tegelikust katkuohust kauem. Peamiselt 19. sajandi lõpus ja 20. sajandi esimesel poolel kogutud katkujuttude puhul pole teada, kuivõrd need veel kogumise ajal aktiivses kasutuses olid, aga asjaolu, et neid üldse rääkida teati, viitab sellele, et informandid pidid neid kelleltki kuulma veel vähemalt 200 aastat pärast katku haiguspuhangute lõppemist Eesti territooriumil. Vähesel määral ilmus katkujutte 20. sajandi alguses ka trükis, kuid võrreldes arhiividesse jõudnud jututüüpidega on nende hulk väga väike. Seega näib, et isegi reaalsetes oludes aktuaalsuse kaotanud mentaalse ohukaardiga seotud loole võidakse omistada sümboolne väärtus, mis toetab jutu püsimist traditsioonis ka edaspidi. Niisiis ei saa katkumuistendite funktsiooniks pidada pelgalt konkreetse haigusohu kajastamist ja instrueerimist sellest pääsemiseks, vaid neil oli oma laiem roll ellujääja-mentaliteedi kandjana. Juttudes leiduvad kirjeldused minevikus ähvardanud ohtudes ellujäämisest edastavad signaali, et toimetulek on võimalik ka tulevikus.

Katkujuttudes esinevad kohamääratlused kahel põhilisel kujul:

1) abistavad kohavihjed,

2) katku algust, liikumist ja lõppu markeerivad kohanimed. 


\section{Abistavad kohavihjed}

Muistenditest nähtub, et katkuvaimul on olemas kindel plaan, millised kohad ta kavatseb läbi käia. Inimene, kes tema saabumise ajal nendest kohtadest eemal viibib, jääb ellu, sest katk piirdub plaanitud kohti läbi käies enamikul juhtudest vaid ühe külastuskorraga. Muistendi lõppedes kaob enamasti ka katk - kui mitte kogu maailmast, siis vähemalt antud piirkonnast. Seega näivad katkuvaimule olevat inimestest olulisemad just kohad. Katku arvepidamine käib kõige sagedamini külade järgi (vt näide 1 ja 2 ), harvemini ka talude järgi (vt näide 3). Viimast arvepidamisviisi võiks pidada isegi ootuspärasemaks, kuna veel 19. sajandi alguses seostati perenimede puudumisel inimesi valdavalt just nende elukohaks oleva talu nimega.

Endamisi oma edasiminekuplaane arutades mainib katkuvaim (näiteks lauldes, pomisedes) kohti, kuhu kavatseb järgmisena minna, ja märkimisväärselt sageli juhtub muistendites mõni inimene seda pealt kuulma. Tihti teab katk neid kohanimesid peast, kuid omaette tüübi moodustavad jutud katkuvaimust, keda kuuldakse valju häälega lugevat kaasasolevas raamatus kirjas olevaid kohti. Seega on klassikaline arusaam saatuseraamatust, kus on kirjas inimeste nimed (vt nt piiblis Ilm 3:5; 20:12), saanud laienduse konkreetsete kohtade lisamise kaudu. Sealjuures armastab katkuvaim pruukida algriimi ja mõõdetud lauserütmi (ehk siis kultuurisidusat väljendusviisi), nagu järgmises külastamist ootavate külade loetelus: "Päinurme, Pätsavere, Suureluige ja Lustivere" või tegevusplaani kirjelduses: "Puisesse ma ei puudugi ega kalaranda ma kaotagi, aga Tuuru külast võtan tuttavaid ja Põgarist võtan peret kaks." Niisiis näib vahel muistendis külade saatuse otsustavat pelk fakt, kas nende nimede algriim kokku sobib. Tegelikult on algriimil siin tõenäoliselt siiski pigem mnemotehniline funktsioon, mis aitab pärimusekandjatel kohtade jada paremini meeles pidada. Selliste nimetsüklite puhul võidi võtta jutu näitlikustamiseks lihtsalt sobivad ümbruskonna kohanimed, millest oldi kuulnud. Samas on tõenäoline, et nii nagu oldi kuulnud üldiselt ümbruskonna külades toimuvast, kuuldi ka sealsetest katkusurmadest.

Järgnevalt esitan mõned näited katkujuttudest, milles katkuvaim reedab oma edasiminekuplaanid, ning toon ära vastavad mentaalsete ohukaartide rekonstruktsioonid.

\section{Näide 1: Päinurme, Pätsavere...}

Koigi vallas Sigapusma külas on Katku kivi ja Katku väli. Kivi peal olema üks jälg ja kepi auk ja nagu raamatu ase ka. Katk on seal järgi vaadanud raamatust, kus ta peab minema. Siis Päinurme ja Pätsavere, Suureluige ja Lustivere - need old katkul käimata (Hiiemäe 1997: 134, 48B). 


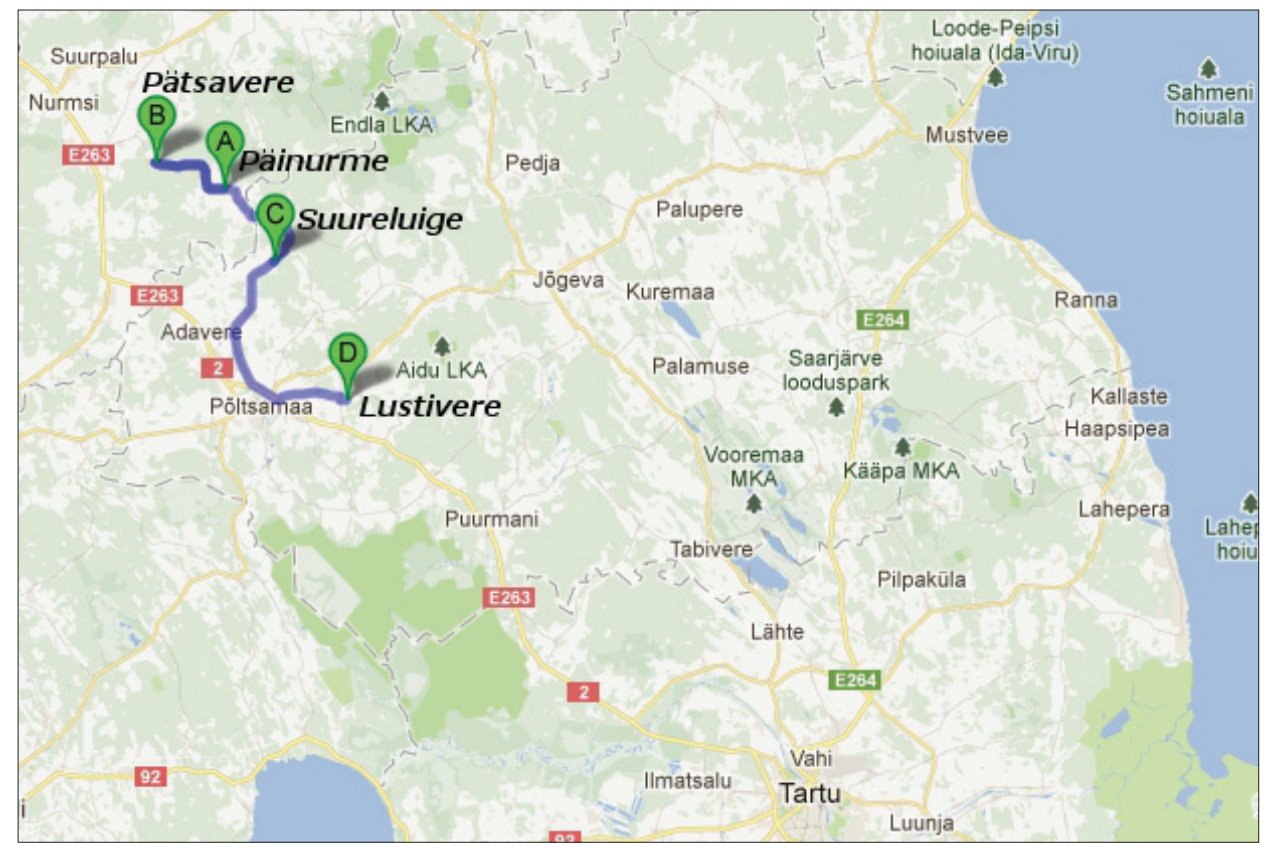

Joonis 1. Mentaalse ohukaardi rekonstruktsioon: "Päinurme, Pätsavere...”.

(8 varianti - kõik variandid on kogutud Põltsamaa ja Peetri kihelkonnast, kus asuvad ka tekstis nimetatud kohad, või naaberkihelkondadest (Kolga-Jaani, Paide), ainult ühe informandi elukoht asub kaugemal (Jõelähtme); muistendis endas kujutatud katkuvaimu teekond hõlmab umbes 40 kilomeetrit.)

Sama süžee teine variant esitab ka eelloo. Katk olevat tulnud naabruses asuvast Koeru kihelkonnast, kus ta oli juba palju inimesi tapnud, Peetri kihelkonda, puhanud ühel Kareda mõisa väljal kivi peal (kivil on väidetavalt katku kehavorm tänini näha) kolm päeva, tema norina peale olevat inimesed minema põgenenud. Ärgates olevat katk läinud Sigapusma poole, leidnud küla tühjana, tahtnud edasi Päinurme minna, aga komistanud kivi otsa (kivil olevat vastav jälg väidetavalt tänini näha). Päinurme-Pätsavere vormelit ei järgne, aga liikumissuund Sigapusma-Päinurme on siingi ette antud (139aA, pisut muudetud kujul trükitud raamatus Eisen 1896, 1920). 


\section{Näide 2: Puisesse ma ei puudugi...}

Ükskord katk tulnd, nisuke väike all poiss olnd, tulnud Sassi rannast. Kepp olnd kääs ja üpand nagu lapsed kepiga üppeid teevad, ütlend isi: "Puisesse ma ei puudugi ega kalaranda ma kaotagi, aga Tuuru külast võtan tuttavaid ja Põgarist võtan peret kaks." No, see olnd heinaaeg, tulnd Puisesse, põle ta Puisesse puutund ka. Aga merekalda peal einamaal üks vana mees niitnd seal, läind selle juure ja ütelnd, et tule, vii teda Muhusse. Vana ütelnd, et pole aega mette, kebe einaaeg. Ja siis poiss ütelnd sedasi: "Et asi seisab selles, et ma pean sind maha sirutama, siis sul siin põesa all aega mõtelda, kas sul on aega või mette. Mina olen katk ja tahan Muhusse Raugile pulma minna."

Ja vanal pole siis aidand muud ühti, kui ronind paati ja poiss tahaotsa. [---] Saand nad siis sõnna Raugile, seal olndki pulmad. Ta keind ka seal pulmatoas. Põle kaua olndki, kui inimesed akand surema. [---] Ronind eese paati jälle ja paat tulnd samaviisi kodu poole nagu minneski, põle sõudmist vaea olnd. Ei vanamehel põle kedagi viga olnd, saand kodu ja akand eina niitma jälle (Hiiemäe 1997: 48aC).

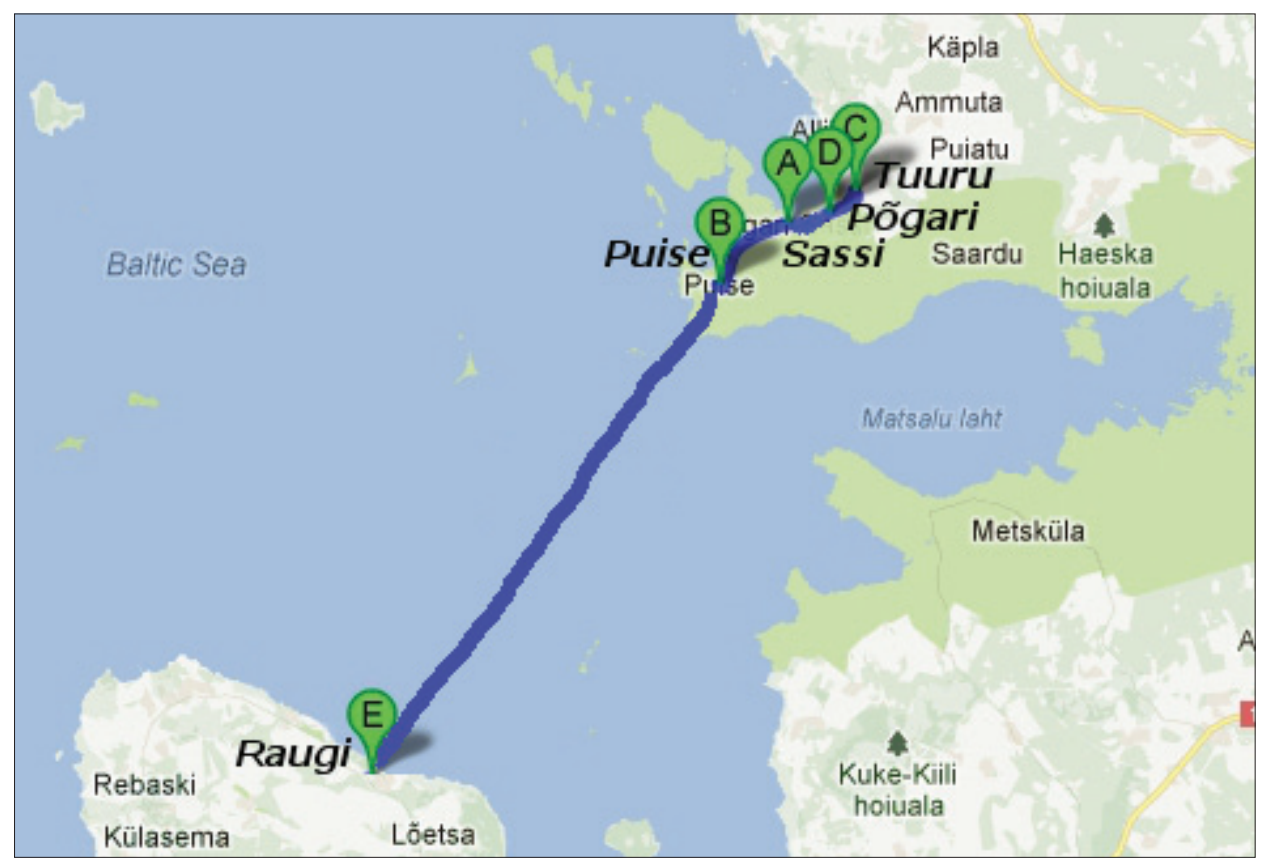

Joonis 2. Mentaalse ohukaardi rekonstruktsioon: "Puisesse ma ei puudugi...". 
(Umbes 3 varianti, kogutud Ridala kihelkonnast, kus asub enamik nimetatud kohti, ja naaberkihelkonnast Lääne-Nigulast. Näitetekstis on näha selge liikumistee: katk tuleb üle mere Sassi randa ja lahkub üle mere Muhu saarele, kokku hõlmab tema liikumistrajektoor muistendis umbes $25 \mathrm{~km}$.)

Väike hulk katkujutte on ilmunud omaaegsetes Matthias Johann Eiseni (1896, 1920) raamatutes. Sellest lähtuvalt võiks mõne hilisema muistendiüleskirjutuse puhul eeldada tema raamatute võimalikku mõju. Ent sellegipoolest on ka hilisemad katkumuistendite üleskirjutused enamasti pärit piirkondadest, mis jäävad muistendis mainitud kohtade lähedusse (vrd nt Hiiemäe 1997: 48B, 139aA).

Kuigi tegelikkuses võis katk levida paralleelselt mitmes suunas, on muistendis parema hoomatavuse huvides katkuvaime üks ja tema liikumiskulg ühesuunaline. Kui see üks katkuvaim on läinud, on järelikult haigusoht möödas.

Siiski ei kujutata katkuvaimu teed alati lineaarsena (see tähendab, et ta ei kasuta kõige ökonoomsemaid liikumismarsruute), vaid see võib olla üsna siksakiline - nagu tõenäoliselt ka haiguse tegelik levik.

Võib väita, et katkuvaimu antud kohamääratlused toimivad muistendites tegutsemisjuhistena: nende paikade elanikud, keda loetelus ei ole, saavad end kindlamalt tunda, ülejäänud aga mobiliseerida end katku vastu võitlemiseks (nt võtta kasutusele pärimuslikud maagilised võtted: jääda öösel ärkvele, magada pead-jalad vaheldumisi, tõmmata talu või küla ümber maagiline piir) või peitu minna.

Vaatamata sellele, et katkujutud koos neis esinevate kohamääratlustega on tõenäoliselt pigem sündmusejärgsed rekonstruktsioonid, esitavad need siiski ideaalväljundi, mida saanuks teha või oleks võinud teha, et ellu jääda, või mis olid põhjused, miks katk mõned kohad puutumata jättis, nagu näiteks järgmises muistenditüübis.

\section{Näide 3: Otsale onule...}

Reinu talu peremees leiab talvel õuest lapsed ja võtab oma tuppa sooja, kuuleb läbi praokil ukse, kuidas need kõnelevad: "Otsale onule, Tikule tädile, Jõnemille lellale."

Tõisel pääval kuuleb peremees, kohe lapsed minna lubanud, kõik ära surnud. Küll tahtnuvad ka Reinu talu rahvast suretada, aga ei ole saanud. Küll olnud lihakauss laua peal, perenaine visanud lihakausi tagasikätt minema, vahel olnud tüdrukitele ilusad säärepaelad maas ja vahel nahapaelad, aga siis keelnud peremees orjad ja lapsed ära, et kedagi tohi võtta, mis maan on. Olgu kui ilusad asjad, kui te võtate, siis surete ära 
nagu Otsa ja teistes taludes surivad ära. Siis jäänud Reinu talu rahvas elama (Hiiemäe 1997: 48bB).

Niisiis tagas muistendiloogika kohaselt ühe talu ellujäämise õige profülaktiline käitumine.

Üheainsa jutu raames loodi kultuurispetsiifilisi ruumilisi koode kasutades mentaalne maakaart, millele mahub nii ohu ilmumine kui ka lõplik pääsemine. Tähelepanek, mille kohaselt üks ja sama mentaalne maakaart hõlmab nii kogu sootsiumit ähvardava ohu tekke kui ka sellest pääsemise, esineb ka Brian Bockingi uurimuses inimese vaimset teekonda kujutavatest mentaalsetest maakaartidest (Bocking 1993: 161).

Muistenditekstides esineb muidki katkult kuuldud liikumisvihjeid:

- Katk on ühekorra Leedris mölland. Tulnd seie Pikitänagu sohe ja ütlend, et peab neid kangeid Pälli mihi ka vaatma minema. Siis ta oli sääl mõne ikka murdnud ka (48E, Hiiemäe 1997: 145).

- Katk kõnnib metsas ja räägib: Patt, patt, patt Paelamaale, kops, kops, kops Kõndu, topp, top, top Toobale! (124cA-C, Hiiemäe 1997: 348-351).

- Katk seisab kivil keset jõge ja kuulutab: "Rütavere, Rütavere, selle ma süün, selle ma süün” (48G, Hiiemäe 1997: 145).

- Harvemini räägib katk ka sellest, kuhu ta ei lähe. Näiteks jätab katk ellu mehe, kellel viljanõu käes, avaldades muuhulgas oma edasised plaanid: Et me vastamisi juhtusime ja jumalavili rukis meie vahel on, jääb sinu pere minust puutumata. Kudril lauldaks kirikulaule, senna ma ka ei lähe. Kõdja kõrtsis (Pikama kõrts) on viina - seda ma kardan. Aga nüüd lähen Päri Oomikülla, senna ei jäta tittegi elama (80bC, Hiiemäe 1997: 211).

\section{Katkupuhangu algust, liikumist ja lõppu markeerivad toponüümid}

Siia kuuluvad kohanimed, mis seotakse katku algamise, liikumise või lõppemisega. Sageli määratletakse muistenditekstides ka talud või külad, mis katkust puutumata jäid. Näiteks võib Katku talu olla nii koht, kust katk algas, kui ka koht, kus katk lõppes, seega nii huku kui ka ellujäämise markeering (vt nt Hiiemäe 1997: 158, 356, 389). Märgatav osa muistendeid käsitleb konkreetset Katku-nimelist kohta siiski just paigana, kus katk otsa lõppes.

Järgmises tekstis on muuhulgas märgitud ka katku liikumissuund Narva poolt Tallinna poole. Kuigi see oli üks peamisi suhtlusliine omaaegsetel kau- 
ba- ja tööreisidel, mainitakse katkujuttudes geograafiliselt nii kaugeid paiku pidepunktidena harva. Selleski näites räägitakse Tallinnast ja Narvast eelkõige suunaorientiiridena, konkreetne katkuvaimu tegevus nendega ei seostu:

Kord möllanud katk jälle rahva seas, tulles Narva poolt, kust ta oma teekonda on alustanud, ja liikunud Tallinna poole. Jõudes Palmse valda Kivikatku kohta, lõppenud äkki katku laastamistöö. Et sääl kohal oli läinud katku ratas kivide vahel katki, on ka talul säilinud nimi Kivikatku (138B, Hiiemäe 1997: 368).

Lisaks kohamääratlustele aitavad katku liikumisteed tuvastada (ja ühtlasi vastavat pärimust elus hoida) maastikuobjektid, näiteks post, mille taha katku vanker väidetavalt kinni jäi, katku jäljega kivid, varemed. Enam märgitakse just takistusi katkuvaimu teel (post, kivi, soo, oja). Seega kaasati katku liikumist kujutavatele ohukaartidele lisaks toponüümidele ka muud maastikulist informatsiooni.

Muistendimaailmas ei lasta end häirida anakronismidest, nagu näiteks populaarses muistenditüübis Simuna katkupostist, mille otsas katku vanker olevat katki läinud ja seega katk pidama jäänud, või mis paari teisendi järgi ehitati pärast katku katkusurnute mälestuseks (kokku on Simuna katkupostist katku peatumisega seotuna umbes 15 teisendit). Viimane katkuepideemia oli Eestis 18. sajandi alguses, Simuna katkupost on aga maamõõtmise ehk triangulatsioonimärk, mis on ehitatud 1849. aastal. Näib, et nendes juttudes ei ole pärimusekandjatele oluline mitte niivõrd ajalooline tõde, vaid pigem asjaolu, et katk lõppes. Järgmine muistend näitab ilmekalt, kuidas kaks seletusversiooni saavad vahel üksteist segamata eksisteerida kõrvuti.

Simunast kaks kilomeetrit lõuna poole asub Katku küla. Selles külas olla katk kõik inimesed maha tapnud. Katk käinud ringi halli kitse näol. Viimase mehe surmanud katk küla põllul. Sinna kohta on suur kivisammas püstitatud tähistamiseks, et katk sinna kinni jäi. Sambale olevat midagi pääle kirjutatud, kirjadest aga õieti aru ei saa. Nooremad inimesed arvavad, et see on mingi maamõotmise märk või mingi muu tähis (136C, Hiiemäe 1997: 366).

Pärimustekstide seas leidub ka mitmeid etümologiseeringuid toponüümidest, mis olevat kujunenud katku tegutsemise iseloomu järgi:

Rahva jutu järgi olevat Tormas möllanud pärast Põhjasõda katk. Sellest katkuajast pärinevat järgmised külanimed: Lullikatku, kus katk löönud veel lulli, Hookatku - sattunud alles hoogu, ja Liikatku, kus ta teinud juba liiga (Hiiemäe 1997: 45A). 
Katkumuistendid edastavad muuhulgas mitmeid ohuga seotud hirmu leevendamise strateegiaid, näiteks kohtab neis korduvalt deemonliku olendi inimlikustamist: lisaks abistavate kohavihjete andmisele soovitab mitmes muistendis just katkuvaim inimestele haiguse eest ohutusse kohta peitu minna või kahetseb, et ei saa mõnda inimest ellu jätta, kuna tolle nimi on katku raamatus kirjas ja ta ei saa seda muuta. Paljudel teistel vanema pärimuse olenditel (nt näkk) sellised humaansed jooned puuduvad ja ka tänapäevastes meediamõjulistes ohunarratiivides kohtab inimlikustamist harva. Pigem on tendents vastupidine - kurjategijaid kaldutakse sõnaselgelt demoniseerima (näiteks rõhutades kurjategijate müstilist tabamatust, inimlike tunnete ja omaduste puudumist). Ent nii vanemates kui ka uuemates juttudes antakse juhiseid profülaktiliseks käitumiseks juhtudel, kui on teada, et oht on lähikonnas. Mitmed hoiatusmuistendid on seega käsitatavad ühtlasi julgestusmuistenditena.

Kirjeldatud lokaliseerimisilminguid sisaldavaid muistendeid on vähemal määral ka mütologiseeritud sõjaröövlite kohta, hilisemast, sõjajärgsest ajast väärivad märkimist lood autodega ringi liikuvatest ja inimesi jahtivatest verevõtjatest (viimaste kohta vt Kalmre 2007). 2000. aastate algul olid populaarsed jutud süstlaga kaasinimesi nakatavatest aidsihaigetest, kelle tegevus lokaliseeriti mõningatesse Tallinna ööklubidesse ja Ida-Virumaale (vrd Sikk 2000, aidsi- ja katkuteemalise folkloori sarnasuste kohta vt Hiiemäe 1999).

On huvitav, et folklooris väga tuntud ja mõneti katkuvaimuga sarnane uskumusolend kurat on Eesti rahvajuttude usundiliste tõekspidamiste kohaselt samuti väga liikuv, kuid temaga seotud muistendites selliseid mentaalseid ohukaarte ei esine. Üks põhjusi näib olevat see, et kurat on võrreldes katkuvaimuga, kes külastas inimesi piiratud aja jooksul ühel korral, liialt kõikjalolev, tema liikumist oleks lihtsalt võimatu kaardistada.

Teisalt on kuradilugudes rõhuasetus esmajoones inimese moraalil ja seega on ta pigem seotud isikutega, mitte kohtadega. Samas on veel tänapäeval maailmas evangelistide ja nelipühilaste kogukondi, kes üritavad saatana ja üldse kurja hauduvate deemonite asupaiku vägagi otseselt kaardistada, märkides kahtlusalused kohad ära reaalsel maakaardil, et neis varitsevatest deemonitest ühiselt võitu saada. Sellist tegevust nimetatakse liikumise siseselt spirituaalseks kaardistamiseks (spiritual mapping) ja kogu võitlusprotsessi kokku spirituaalseks sõjaks (spiritual warfare) (vt pikem ülevaade Holvast 2009).

Kirjeldan seda nähtust lühidalt, kuna näen sarnasusi eelkirjeldatud mentaalsete ohukaartide loomisega usundilistes juttudes. 


\section{Lokaliseerimisstrateegiaid tänapäeval: spirituaalne sõda ja kurjategijate liikumisteed}

Spirituaalse sõja aktivistid lähtuvad eeldusest, et kurat ja tema käsilased on maailmas reaalselt tegutsev jõud, mis külvab hirmu ja paneb inimesi patustama, ning töötavad selle nimel, et lokaliseerida kohad, milles arvatakse deemonlikku mõju levivat (lähemalt spirituaalse sõja liikumise väljendusvormidest internetis vt Howard 2009: 167). Ühest paljudel spirituaalse sõja veebilehtedel korduvast tsitaadist saab meetodi kohta täpsema pildi: "Spirituaalne kaardistamine on mingit piirkonda või inimesi puudutava spirituaalse teabe sortimise ja kaardile paigutamise protsess. See võimaldab meil näha, kus vaenlane antud konkreetses paigas või inimrühma suhtes paikneb ja Saatana varjatud plaani juurutab." (allikas: Spirituaalne kaardistamine tõhusa spirituaalse sõja tarbeks: http://www.keepersofhisgates.com/spiritualmapping2.htm). Kaardistamistegevuse õigustuseks tuuakse paljudel vastavatel lehtedel (nt India taustaga leht http://www.geocities.ws/sajisheenas/mapping.htm) piibli kirjakoht 4 Ms 13: 1-2, 17-20, milles Mooses saadab Issanda käsul mehed Kaananimaad ja rahvast uurima. Spirituaalne kaardistamine võib toimuda paberil või ka arvuti abil ning hõlmata terveid linnu, ja selline kaardistamine võib kesta aastaid.

Mingile isikule või territooriumile suunatud deemonlik rünnak toimub spirituaalse sõja teooria kohaselt antud piirkonnas levinud usundis peituvate deemonite kaasabil, kes võivad nakatada oma meelsusega ümbruskonna inimesi, pannes neid omaks võtma ja praktiseerima taunitavaid rituaale ja kombeid (näiteks homoseksuaalsuse või vabamüürluse vormis) (Holvast 2009: 194). Saatanlike kontrollikeskuste tuvastamisel võetakse seega appi piirkondlik folkloor, näiteks Bangladeshi korduvate üleujutuste ja tormide põhjuseks arvati kohalikus pärimuses tuntud raevuka vaimolendi Rudra mõju, kunagise Jugoslaavia territooriumil toimunud sõda seostati piirkonnas asuvate paganlike (ehk siis nelipühilaste vaatenurgast deemonlike) kultuspaikade olemasoluga (vrd Holvast 2009: 216-217). Seega on siin kombineeritud liikuvate ja paiksete deemonlike ohuallikate kaardistamine.

Huvitav on jälgida siingi kontekstis profülaktilise kaitsemaagia kasutamist deemonliku mõju pareerimiseks: näiteks pöördutakse jumala poole palvega, et ta looks kaitsva "heki" ümber rünnatava inimese või koha. Samuti kasutatakse "kinnipanevaid" palveid, mille eesmärk on siduda kurjad vaimud mingi kindla kohaga, et nad ei saaks oma mõju mujale laiendada. (Kinnipanemine ja kaitsva ringiga ümbritsemine on paljudes just mittekristlikes usundites tuntud kaitsemaagiavõte.) Paljudel juhtudel ei ole piirkonna elanikud ise väidetavast deemonlikust mõjust ega selle vastu suunatud palvetest teadlikud, sest kogu spirituaalse sõja viib läbi väike aktivistide rühm. 
Spirituaalse sõja liikumise sünniajaks peetakse 1989. aastat, mil Ameerika Ühendriikides tekkinud idee omandas kiirelt rahvusvahelise ulatuse, levides esmajoones edasi Ladina-Ameerikasse (Holvast 2009: 57, 67). 2000. aastate alguses hakkas liikumine lagunema (Holvast 2009: 110), kuid tehnika kui selline on kaugel väljasuremisest, temaatilisi veebilehti võib leida kümneid (nt Ameerika, Ladina-Ameerika, India, Keenia lähtekohaga). Ohtude narratiivne ja lisaks kohati lausa füüsiliselt kartograafiline lokaliseerimine toimub seega ka tänapäeval.

Religiooniteadlane Réne Holvast nimetab oma raamatus spirituaalset kaardistamist metafooriga hirmu geograafia (Holvast 2009). Üldiselt on hirmugeograafia mõistest lähtuvad uurimused seostatavad peamiselt feministliku diskursusega ja nende, peamiselt alates 1990. aastate lõpust ilmunud tööde puhul ongi esiplaanil ruumitaju käsitlemine sooaspektist (vrd Tüür 2001: 86). Näiteks on jälgitud naiste hirme mingit tüüpi ruumiüksuste (nt maa-alused parklad) või konkreetsete ruumiüksuste (nt mingi konkreetne linnaosa) suhtes ja uuritud sellest tingitud mentaalsete maakaartide loomist turvalise teekonna konstrueerimisel. Tulemuseks on nn moraalikaardid, millel kajastuvad elanike tõekspidamised, mis ei pruugi põhineda isiklikul kogemusel piirkonna ohtlikkusest (Tüür 2001: 88). Ka muude usundiliste juttude kohta võib öelda, et need esitavad üldist kultuurilist teadmust, mitte tingimata üksikisiku reaalselt läbielatud ohukogemust antud kohaga seoses. Ühe sellise tänapäevase kontsentreeritud hoiatusnarratiivina on vaadeldavad näiteks Tallinna vanalinnas leiduvad taskuvaraste eest hoiatavad märgid.

2012. aasta sügisel ringles Facebookis eestikeelsete kasutajate hulgas põhiliselt naiste (aga ka mõne mehe) vahendusel ingliskeelne põhjalik õpetus selle kohta, kuidas naised saavad hoida end vägistajate kätte sattumast (algversioon: http://www.tumblr.com/tagged/avoid\%20rape - 18. aprill 2013). Lisaks profülaktilistele käitumisjuhistele oli loetletud terve rida ohtlikke kohti, küll mitte kohanime järgi, vaid lähtuvalt kohamääratlusest, näiteks kõige ohtlikuma kohana olid välja toodud supermarketite parklad (eriti maa-alused), teisel kohal olid kontorihoonete parklad ja garaažid, kolmandal avalikud WCd, lisaks olid ohtlikena märgitud pimedad pargid ja tänavaservad. Et kurjategijate tegelik liikumistee on teadmata, muutuvad siin ohukandjaks mitte inimesed, vaid kohad, mille kaardistamisega püütakse naistele anda abistavaid vihjeid. Samas loovad sellised hoiatuslood ühtaegu ka hirmu- ja ohutunnet lokaliseerivat kohapärimust. Muuhulgas on märkimisväärne, et kõik need ohukaardid lähtusid ainult linnaruumist.

Ajakirjanik Rain Kooli tõi 2010. aastal portaalis Delfi.ee ilmunud arvamusloos "Hirmu geograafia ehk valesti kardetud" välja tõsiasja, et enamik inimesi peab kõige ohtlikumaks üksildasi pimedaid kohti, kuid statistiliselt toimub kõige rohkem vägivallakuritegusid tuttavas miljöös, näiteks kodus ja 
tuttavate inimeste pool. Artiklile järgnenud kommentaariumiarutelus annab üks kommenteerija küll pisut iroonilise maiguga, kuid otsesõnalise kaardistamissoovituse: "pange laibad punaste täppidena kaardile ja saate õige pildi, muu on luule" (6. jaanuar 2010, www.delfi.ee).

Üheks paljude eestimaalaste mentaalse ohukaardi punktiks sai pärast 2009. aasta novembris toimunud nn kurikamõrva Snelli tiigi ümbrus Tallinnas, seda vaatamata suurele tõenäosusele, et tabamata mõrvar hoidub edaspidi sealt pigem eemale ja liigub muudes kohtades. Omalt poolt aitas sellele mentaalse ja narratiivse fookustamise protsessile kaasa meedia, näiteks Delfi (27. novembril 2009) artikkel kontraste rõhutava pealkirjaga "Kurikamõrvar tegi armastatud Snelli pargist hirmupesa" (Delfi 2009), millele järgnevates lugejakommentaarides leiduvad korduvad kinnitused: "Kuid jah, peab tunnistama, et enne ikka hilistel õhtutundidel sai jalutatud küll üksi pargis veel kuigi teadsin, et võib pätte ja narkareid seal ikka leiduda. Enam ikka ei taha päevalgi väga minna sinna või üksikuid tänavaidpidi [käia]" (kasutaja NeikuK) või "korralikud inimesed ärge käige säärastes kohtades" (kasutaja köbels) või isegi retrospektiivselt tagasihaaravad konstateeringud "See kant on minu jaoks alati seostunud õudsa kandiga" (kasutaja õudne kant) või "Shnelli tiigi pargis on varemgi väga raskeid röövimisi ja mõrvu toimunud, samuti ohtralt kotijookse ja niisama peksmist. See on üks ohtlikumaid paiku tallinnas" (kasutaja nimega meeldetuletus). Kurjategija ja kuriteopaiga seotust (kooskõlas uskumusega, et kurjategija peab sisemise sunni tõttu teopaika tagasi tulema) rõhutab kommentaar: "hakkan spetsiaalselt seal kandis jalutama, et järsku satub ette midagi.. mõrvar hakkab huvi tundma oma kuriteopaiga kohta" (kasutaja huviline). Nagu näha, on nüüdisaja inimeste mentaalsed ohukaardid rohkemal või vähemal määral korrelatsioonis meedia esitatud kuriteoteadete ja rõhuasetustega. Snelli park hakkas aktiivselt hirmukaardilt kaduma alles kaks aastat hiljem, pärast kurjategija süüdimõistvat otsust, milleni jõudmist meedia taas ulatuslikult kajastas. Vestlusest Tallinna elanikega aimub, et Snelli pargil on eeldusi jääda latentse ohupaigana inimeste teadvusse ka edaspidi: tegemist on "metsiku kohaga" ehk kohaga, kus puuduvad elumajad, ühtlasi mõttelise piirialaga Kesklinna, Põhja-Tallinna ja Balti jaama vahel (viimast tuntakse juba aastakümneid kui äärerühmadesse kuuluva kontingendi kogunemis- ja tegevuspiirkonda) (vt piirialade tajumisest linnaruumis Lynch 1960).

Kui tuua võrdlus vanema pärimusega, sarnaneb eeltoodud näidetes loodud mentaalne ohukaart pigem paikse iseloomuga mütoloogiliste ohuallikate (nt surnuaial ilmuvad vaimud), kui liikuva iseloomuga mütoloogiliste ohuallikate (katkuvaim) kaardistamise tulemusega. Tabamata kurjategijad on aga inimeste meeltes kinnistunud pigem katkuvaimu kombel: nende liikumistee on teadmata ja järgmised teod prognoosimatud, sellest hoolimata püütakse luua lokaliseerivaid seoseid. 


\section{Lood autoga liikuvatest ahistajatest}

2012. aasta märtsi lõpus ilmus Eesti meedias sageli šokeerivaid uudiseid 9aastase vene tüdruku Varvara kadumisest ja hiljem mõrvatuna leidmisest Narvas. Esialgse versiooni kohaselt istus tüdruk enne kadumist võõrasse autosse. Hiljem see versioon kummutati, kuid seos autodega jäi edasistegi hoiatuslugude püsielemendiks. Aprilli esimestel päevadel jagati mitme Tartu vallas elava inimese Facebooki konto kaudu üleskutset ettevaatusele, kuna üleskutse autor oli enda sõnul usaldusväärsest allikast kuulnud, et Tartumaal Kõrvekülas kutsus keegi mees ühte last punasesse autosse ja lubas ta koju viia. Järgneb seostamine Narva juhtumiga, üleskutse postitaja märgib: "Väga tõenäoliselt on tegemist sama Narva kurjategijaga.” Nagu katkumuistendites, lokaliseeritakse ka siin ohu levikutee kodu ümbruses ja info selle kohta levib aktiivselt mõnekümne kilomeetri ulatuses lokaliseerimispaigast. Postitus annab ka julgestavaid käitumisjuhiseid, kutsudes üles vältima võõrastega rääkimist ja punaseid autosid. Ei olegi oluline, kas tegemist oli Narva kurjategijaga või kas üldse oli tegemist pahatahtliku inimesega, strateegia võimaldab inimestel vabaneda sunnitud passiivsusest ja midagi enda kaitsmiseks ette võtta. Narratiivi oletatav reaktsiooniraadius on taas paarkümmend kilomeetrit: vestlustest emadega, kes elavad oma perega Kõrveküla naaberasumites, selgus, et saadud info mõjus neile mobiliseerivalt, näiteks keelasid nad lastel üksi ringi liikuda, hakkasid jälgima ümbruses liikuvate autode värvust jms. Seega lähtub teatud kohtade eelistamine või vältimine narratiivselt konstrueeritud mentaalsest ohukaardist.

2012. aasta oktoobris jagati Facebookis järgmist hoiatuslugu:

Annan teada, et Mustamäel on liikvel halli sõiduautoga "kommionu". Mehel on ninal arm ja ta on riides korralikult. Käitumismalliks on avalikus kohas auto peatamine ja käskival toonil inimese autosse kutsumine pakkumisega koju viia. Täiskasvanu puhul selline käitumine reeglina tulemusi ei anna kuid väikesele koolilapsele võib see mõjuda küll. Tegu on üpris tulemusliku psühholoogilise nõksuga. Kindlasti tasub olla tähelepaneik ka mujal, sest ega keegi ei tea, kas see mees on täna hoopis Teie kodu lähedal. Palun rääkige kodus oma lastega sellistel teemadel ikka ja jälle! Samuti palun Teil seda jagada, et vajalik info jõuaks võimalikult paljude inimesteni. (8.10.2012)

Paralleelselt (samuti 2012. aasta oktoobris) jõudis meediasse (ajalehed, veebiajalehed ja nendele viitamised sotsiaalmeedias) lugu Raplamaal Juurus (s.o nii Narvast kui ka Kõrvekülast üle 150 km kaugusel) tegutsevast tabamatust halli autoga meesmaniakist, kes pakub lastele kommi ja hirmutab ka noori naisi. Siinset meest ei samastata Narva kurjategijaga, kuna tema tegutsemi- 
sest oli teateid juba varem, kuid lokaliseerimist toetab kirjeldatud liikumisviis: kurjategija liigub autoga. Massimeedia laineprintsiibile omaselt saab Juuru "hull" rohkem meediakajastust just pärast seda, kui on levinud teade tabamata kurjategijast Narvas. Korduvad üleskutsed suunavad inimesi käsitama potentsiaalse kurjategijana iga inimest, kes vastab kahele kriteeriumile: kõnetab lapsi ja sõidab autoga. Samamoodi süüdistati katku ajal tõenäoliselt süütuid rändureid katkukülvamises või peeti neid katkuvaimuks.

Katkujuttude lokaliseerimisahela viimane lüli on katku lakkamine antud piirkonnas. Üksikutes juttudes mainitakse laiemat geograafilist ala (nt mõnel juhul räägitakse katku lõppemisest kogu maamunal). Kurjategijatega seotud tänapäevaste juttude lokaliseerimisahel lõpeb kurjategija vahistamisega või siis uudise tuhmumisega uute uudiste pealetulemise tõttu (vrd Hiiemäe 2008: 247). Jutud Snelli pargi ohtlikkusest hakkasid vaibuma 2013. aastal, mil kurikamõrvar 17 aastaks vangi määrati (Kuul 2013), 2013. aasta kevadeks olid vaibunud ka jutud lapsi ohustavatest autodega ahistajatest, oodates siiski latentsel kujul uut aktiveerumisfaasi. 2013. aasta aprillis jõudis meediasse uudis purjus mehest, kes oli ühes Tallinna toidupoes tülitanud avalikult komplimentidega 11aastast tüdrukut (nt PM TC 2013). Ajalehe Postimees TallinnCity internetiversioonis artiklile järgnenud kommentaarides tõmmatakse mitmel korral jälle otsene paralleel Narva kurjategijaga, näiteks: "minu jaoks võib olla tegemist potensiaalse kurjategijaga, kes võib vabalt olla ka Narva Varvara juhtumi kurjategija" (Postimees.ee, 21.04.2013), samuti kinnitasid mitmed vanemad, et ei julge oma lapsi sinna poodi enam saata - loodud ohukaart leidis rakenduse ka käitumuslikul tasandil.

Tänapäeva ohujuttudes võib täheldada lisaks lokaliseerimist kontrasti 'Eestis ja mujal' ning 'linnas ja maal' baasil, seega on tajutud vahekaugused relatiivsed ja erinevad objektiivsetest vahemaadest. Isegi kui mingi ohtlikuks kuulutatud koht on Eesti vahetus läheduses (nt Soomes), tajutakse seda vähem aktuaalsena kui Eestis asuvaid piirkondi. Küsitletud inimesed väitsid, et Lätis toimuv läheb neile üldiselt rohkem korda kui Venemaal toimuv - Venemaa on oma suuruse tõttu hoomamatum ja seda käsitletakse rohkem kultuurilise teisena. Järgnevast näitest selgub, et mentaalsed kaardikujutised on visad muutuma ka siis, kui inimene on juba aastaid mujal elanud. Nimelt ütleb mõned aastad Ameerika Ühendriikides elanud sportlane Martti Aljand Postimehele antud intervjuus: "USA on nii suur, et need uudised, mida sa loed, $a$ la keegi kuskil tapeti, siis see on alati nii kaugel, umbes nagu me loeksime, et Venemaal lasti keegi maha. Väga ei huvita ju. Aga kui loed, et kuskil Tallinna kesklinnas midagi juhtus, siis hakkad mõtlema, et mis tänaval see oli ja millal ma seal viimati kõndisin" (Värv 2013). 


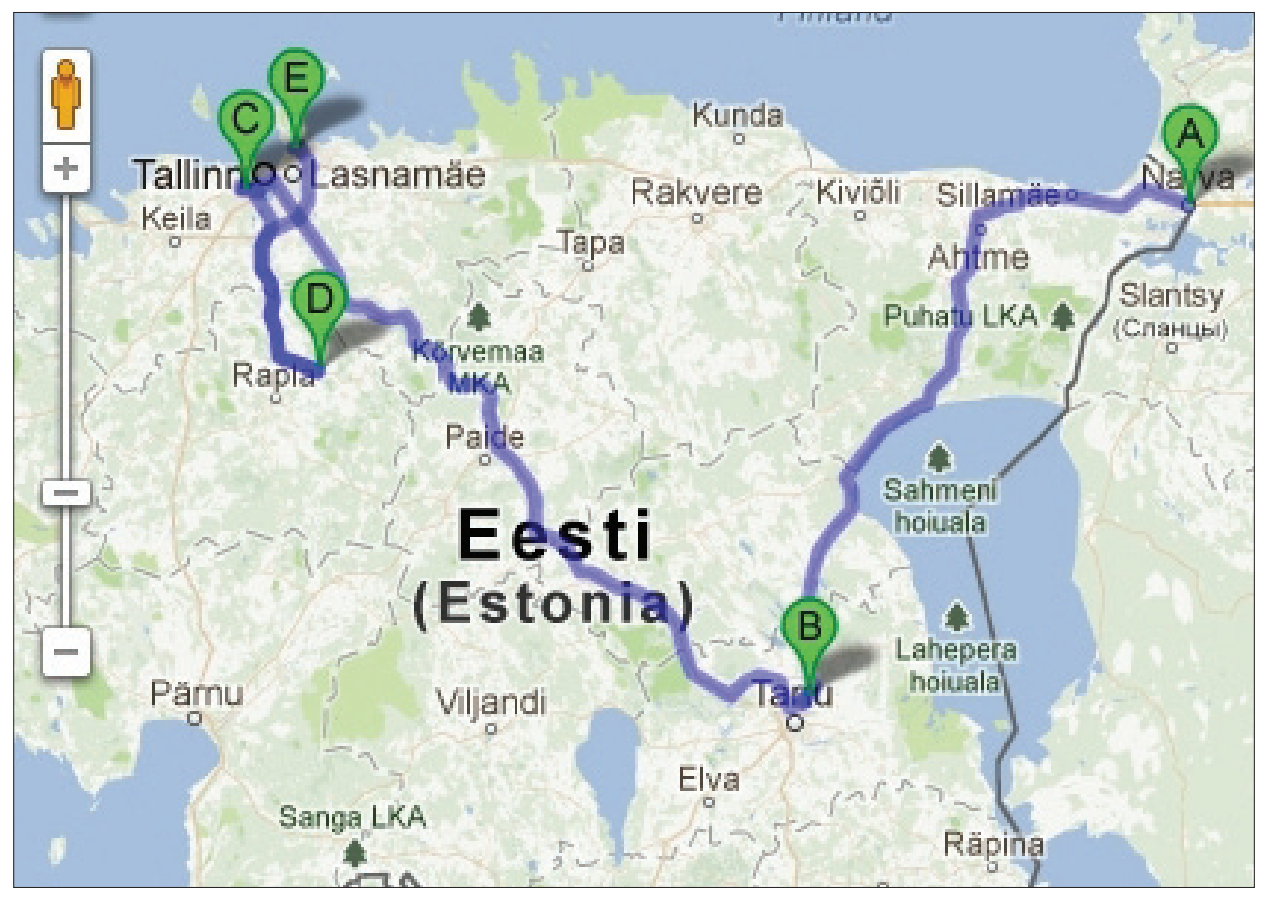

Joonis 3. Tänapäevase mentaalse ohukaardi rekonstruktsioon: autoga liikuvate lastekõnetajate seostamine Narva kurjategijaga.

Võib öelda, et uskumusjuttudes esitatud ohukaardid on ühtaegu nii minevikus toimunud sündmuste toimumise paik kui ka ajatu ruumimudel. Kui selline kaart on kord kuju omandanud, kaldub see sarnaste uute ohuolukordade ilmnemisel uuesti aktiveeruma, saades täienduseks veelgi uusi geograafilisi pidepunkte.

Kui suur osa kognitiivse kaardistamise autoreid analüüsib reaalseid kaarte, mille nad on palunud oma intervjueeritavatel joonistada (nt Lynch 1960; Matei et al. 2001; Wilde 2007), siis minu töös on rõhuasetus narratiivil - sellel, kuidas ohukohtade kaardiline kujutamine väljendub jutus ja kui suur on nende kaartide kujundamisel just jutuna kuuldu, mitte isikliku ohukogemuse osatähtsus. Siiski on mõned autorid käsitlenud ka kommunikatiivsete protsesside rolli inimeste hirmude ja hirmumaakaartide konstrueerimisel, näiteks Matei et al. (2001) Los Angelesi linnaruumi segmenteeritud tajumist vaatlevas töös. Mõningaid varem ilmunud töid sain kasutada teoreetilise baasina: näiteks leidsid ka minu materjali põhjal kinnitust Kevin Lynchi väited piiride, piirialade ja ruumiliste sõlmpunktide erilise tajumise kohta (vrd Lynch 1960), samuti haakusid minu materjaliga Downsi ja Stea (2011) põhidefinitsioonid. 
Mahu piiratuse tõttu esitasin artiklis vaid mõned ohukaartide näited. Kahtlemata oleks huvitav luua ulatuslikum statistiline ülevaade katkujuttudes esinevate kohamääratluste ja nende jutustajate elukohtade põhjal, nagu seda on püüdnud teha oma muistendimaterjali varal näiteks Timothy Tangherlini (2010). See võimaldaks täiendavalt kontrollida minu väidet, et usundilistes juttudes kirjeldatud ohukohad piirduvad üldjuhul mõnekümnekilomeetrilise geograafilise areaaliga. Kui kaaluda tänapäevaste ohukohti käsitlevate narratiivide uurimisperspektiive, pakub huvi Bin Jiangi (2012) idee, mille kohaselt võiks arvuti abil koostada kaardid, mis hõlmaksid tervete linnade mentaalseid representatsioone; näiteks võiks võtta aluseks mingi rühma sotsiaalmeedia postitustes leiduvad kirjeldused teatud piirkondade tajumise kohta ohtlike või mitteohtlikena. Kuna käesoleva artikli tänapäevaseid ohukaarte käsitlevad näited kogunesid suhteliselt juhusliku valimi põhjal, oleks kindlasti asjakohane jätkata sellise kaardistamise uurimist teadlikumalt määratletud valimi alusel.

Mis puutub kasutatud terminoloogiasse, siis on kohati kritiseeritud terminite kognitiivne kaart ja kognitiivne kaardistamine ülekasutamist (nt Rescorla 2009), näiteks on nendega vahel tähistatud ka selliseid mäletamis- ja tajumisviise, mis ei ole seotud ruumi ja kohtadega. Osalt sellest asjaolust tingitult on mõned autorid pruukinud paralleeltermineid, nt Juha Pentikäinen (1995: 270-271) kasutab oma šamanismialastes töödes kognitiivsete kaardistamisprotsesside kirjeldamisel terminit 'meele grammatika' (grammar of mind). Eestikeelsetes uurimustes on kasutatud nimetuse kognitiivne või mentaalne kaart kõrval ka terminit kujutluskaart (vrd Liiber \& Palang 1995). Käesolevas töös tundus sobiv rääkida siiski mentaalsetest või kognitiivsetest kaartidest.

\section{Kokkuvõte}

Püüdsin artiklis näidata, et sõltumatult sellest, kas tegemist on vanade pärimustekstidega või tänapäevase meediamõjulise jutustamisega, tingivad inimeste ruumikäitumise otsused, mis tehakse kognitiivsetele ohukaartidele tuginedes. Need kaardid kujutavad endast ruumilise taju ja maailma ruumilise korrastatuse visualiseeritud ja jutuvormis esitatud väljendust. Need esindavad kombinatsiooni pärimuslikult ja kultuuriliselt etteantud teabest ning individuaalkogemusest, kajastades sageli operatiivselt turvalise territooriumi piiride nihkumist võõra ja ohtliku olendi sissetungi (või selleteemalise narratiivi kuulmise) tagajärjel.

Usundilise taustaga järelduste ja lihtsalt mõistlike ettevaatusabinõude vaheline piir pole alati selgelt määratletav. Siiski väärib mentaalsete ohukaartide 
puhul esiletoomist tõsiasi, et need on loomuldasa lihtsustatud. On täheldatud, et just ohu-ja kriisiolukorras võivad inimesed näha juhuslike sarnasuste puhul seaduspärasusi ja otsida toetust rituaalsetelt kaitsemehhanismidelt. Näiteks võib märgata kalduvust asuda usundilise teadmuse põhjal konstrueeritud ohukohtade (kombinatsioonis stereotüübistatud ohtlikuks peetavate inimestega) puhul demoniseerima mingit kultuurilist stereotüüpi, samas kui mittestereotüüpses kohas avalduv oht võib jääda tähelepanuta (vrd sarnased tähelepanekud Matei et al. 2001). Siiski polnud käesoleva artikli eesmärk jõuda selgusele, kuivõrd aitavad sellised kaardistamisstrateegiad tegelikult inimestel oma julgeolekut tagada. Pigem üritasin näidata selliste ohukaartide tähtsust info selektiivsel kogumisel ja mäletamisel ning sellest lähtuva edasijutustamise ja käitumise tingijana. Lisaks pragmaatilistele tekkepõhjustele (abivahend ohutuks liikumiseks ruumis) kannavad narratiivsed ohukaardid subjektiivset toimetulekutunnet toetavat julgestusfunktsiooni.

\section{Kirjandus}

Arukask, Madis 2007. Setu lüroeepilise rahvalaulu ruumimudelist. Sator 6. Artikleid usundi- ja kombeloost. Tartu: EKM Teaduskirjastus, lk 213-229 (http://www.folklore. ee/rl/pubte/ee/sator/sator6/10madisarukask.pdf - 30. oktoober 2013).

Bender, Barbara 2002. Time and Landscape. Current Anthropology 43, Supplement: Repertoires of Timekeeping in Anthropology (Aug. - Oct., 2002), lk S103-S112 (doi: 10.1086/339561).

Bocking, Brian 1993. 'If you meet the Buddha on the map'. The notion of mapping spiritual paths. Cosmos 9, lk 159-162 (https://eprints.soas.ac.uk/123/1/Buddha_Map. pdf - 30. oktoober 2013).

Downs, Roger M. \& Stea, David 2011. Cognitive Maps and Spatial Behaviour: Process and Products. Dodge, Martin \& Kitchin, Rob \& Perkins, Chris (toim). The Map Reader: Theories of Mapping Practice and Cartographic Representation. Hoboken: John Wiley \& Sons (doi: 10.1002/9780470979587.ch41).

Eisen, Matthias Johann 1896. Kodused jutud. 75 wanaaegist juhtumist meie maalt. Tallinn: G. Pihlakas.

Eisen, Matthias Johann 1920. Eesti kohalikud muistejutud. Tallinn: Eestimaa Kooliõpetajate Vastastiku Abiandmise Seltsi raamatukauplus.

Golledge, Reginald G. \& Stimson, Robert J. 1997. Spatial Behavior: A Geographic Perspective. New York, London: The Guilford Press.

Herman, David 2000. Narratology as a cognitive science. Image \& Narrative. Online Magazine of the Visual Narrative. Issue 1. Cognitive Narratology (http://www. imageandnarrative.be/inarchive/narratology/davidherman.htm - 25. oktoober 2013). 
Herman, David 2003. How stories make us smarter. Narrative theory and cognitive semiotics. Recherches en Communication 19, lk 133-153 (http://sites-test.uclouvain.be/ rec/index.php/rec/article/viewFile/5231/4961 - 30. oktoober 2013).

Hiiemäe, Reet (koost) 1997. Eesti katkupärimus. Monumenta Estoniae antiquae II. Eesti muistendid. Mütoloogilised haigused I. Tartu: EKI folkloristika osakond, EKM eesti rahvaluule arhiiv.

Hiiemäe, Reet 1999. Katk ja aids - sarnaste fenomenide käsitlemine rahvapärimuses. Kuuldust-nähtust. Tänapäeva folkloorist IV. Tartu: Eesti Kirjandusmuuseum, lk 31-44.

Hiiemäe, Reet 2008. Strategien zur Bewältigung von Ängsten durch massenmediales Erzählen. Schmitt, Christoph (toim). Erzählkulturen im Medienwandel. Rostocker Beiträge zur Volkskunde und Kulturgeschichte, 3. köide. Rostock: Waxmann, lk 245-255.

Holvast, Réne 2009. Spiritual Mapping in the United States and Argentina, 1989-2005: A Geography of fear. Leiden: Brill.

Howard, Robert Glenn 2009. Crusading on the Vernacular Web: The Folk Beliefs and Practices of Online Spiritual Warfare. Blank, Trevor J. (toim). Folklore and the Internet: Vernacular Expression in a Digital World. Logan: Utah State University Press, lk 159-174.

Jarz, Ewald 1997. Entwicklung multimedialer Systeme. Planung von Lern- und Masseninformationssystemen. Wiesbaden: Springer.

Jiang, Bin 2012. Computing the Image of the City. Cornell University Library (http:// arxiv.org/abs/1212.0940 - 25. oktoober 2013)

Kalmre, Eda 2007. Hirm ja võõraviha sõjajärgses Tartus. Pärimuslooline uurimus kannibalistlikest kuulujuttudest. Tänapäeva folkloorist 7. Tartu: EKM Teaduskirjastus.

Labrie, Vivian 1999. Going through hard times: A topological exploration of a folktale corpus from Quebec and Acadie. Fabula 40, nr 1/2, lk 50-73 (doi: 10.1515/fabl.1999.40.12.50).

Liiber, Ülle \& Palang, Hannes 1995. Kujutluskaardid: Eesti kooliõpilased Euroopast. Kurs, Ott \& Merikalju, Laine (toim). Eesti Geograafia Seltsi aastaraamat 29, 1. Tallinn: Teaduste Akadeemia Kirjastus, lk 48-167.

Lyle, Emily 1993. Internal-external memory. Cosmos. The Yearbook of the Traditional Cosmology Society 9. Edinburgh: Edinburgh University Press, lk 63-74.

Lynch, Kevin 1960. The image of the city. Cambridge: MIT Press.

Matei, Sorin \& Ball-Rokeach, Sandra J. \& Linchuan Qiu, Jack 2001. Fear and Misperception of Los Angeles Urban Space. A Spatial-Statistical Study of Communication-Shaped Mental Maps. Communication Research 28 (4), August, lk 429-463 (doi: 10.1177/009365001028004004).

Metsvahi, Merili 2007. Indiviid, mälu ja loovus. Ksenia Mü̈̈rsepa mõttemaailm folkloristi pilgu läbi. Tartu: Tartu Ülikooli kirjastus.

Pentikäinen, Juha 1995. The Revival of Shamanism in the Contemporary North. Kim, Tae-Gon \& Hoppál, Mihály (toim). Shamanism in Performing Arts. Bibiotheca Shamanistica 1. Budapest: Akadémiai Kiadó, lk 263-272. 
Rescorla, Michael 2009. Cognitive Maps and the Language of Thought. British Journal for the Philosophy of Science 60 (2), lk 377-407.

Ryden, Kent C. 1993. Mapping the Invisible Landscape. Folklore, Writing, and the Sense of Place. American Land \& Life. Iowa: University of Iowa Press.

Stanonik, Marija 1993. Possibilities of psychological interpretations of the literary folklore. Narodna umjetnost: hrvatski casopis za etnologiju i folkloristiku 30 (1). Svibanj, lk 157-165.

Tangherlini, Timothy 2010. Legendary Performances. Folklore, Repertoire and Mapping. Ethnologia Europaea. Journal of European Ethnology 40 (2), lk 103-115.

Tolman, Eduard 1948. Cognitive maps in rat and men. Psychological Review 55, lk 189-208.

Tüür, Kadri 2001. Ruumi poolt määratud: naiste hirmugeograafiast. Ariadne Lõng. Nais- ja meesuuringute ajakiri II, 1/2, lk 86-92.

Wilde, Andreas 2007. Mental Mapping in Herat. ASIEN 104, lk 119-134 (http://www. dga-ev.de/articles/A104_119_134.pdf-30. oktoober 2013).

\section{Ajakirjanduslikud allikad}

Delfi 2009 = Kurikamõrvar tegi armastatud Snelli pargist hirmupesa. Delfi 16. aprill (http://www.delfi.ee/news/paevauudised/110_112/kurikamorvar-tegi-armastatud-snellipargist-hirmupesa.d?id=27195119 -27 . november 2013).

Haravee, Juhan 2013. Kalmistumõrvar ei tundnud vanureid pekstes halastust. Õhtuleht 16. aprill (http://www.ohtuleht.ee/517304 - 25. november 2013).

Kooli, Rain 2010. Hirmu geograafia ehk valesti kardetud. Delfi.ee 6. jaanuar (http:// www.delfi.ee/news/paevauudised/arvamus/rain-kooli-hirmu-geograafia-ehk-valestikardetud.d?id=28316169 - 30. oktoober 2013).

Kuul, Marek. Kalmistumõrvar sai 17-aastase vanglakaristuse. ERR uudised, 23. aprill 2013 (http://uudised.err.ee/index.php?06277697 - 25. november 2013).

LL 2011 = Vanurit röövinud kurikael saadi kätte. Lõunaleht 10. november (http://www. lounaleht.ee/index.php?page=1\&id=8415 -25 . november 2013).

PM TC 2013 = Umbjoobes ahistaja püüdis läheneda 11-aastasele tüdrukule. Postimees TallinnCity 20. aprill (http://www.tallinncity.ee/1209400/umbjoobes-ahistaja-puudislaheneda-11-aastasele-tudrukule - 26. november 2013).

Sikk, Rein 2000. Aids ajab liikvele muistsed katkujutud. Eesti Päevaleht 11. oktoober (http://epl.delfi.ee/news/melu/aids-ajab-liikvele-muistsed-katkujutud.d?id=50792640 25. november 2013).

Värv, Maarja 2013. Martti ja Triin Aljand, kaugelt ära, koju! Postimees 30. märts, lk 5 (http://sport.postimees.ee/1185142/martti-ja-triin-aljand-kaugelt-ara-koju - 31. oktoober 2013). 


\title{
Summary
}

\section{Traditional Place Designations and the Mapping of Mobile Sources of Danger in Belief Narratives}

\author{
Reet Hiiemäe
}

Keywords: belief narratives, cognitive mapping, places, narrative localisations, mediainfluenced narration

The article provides an overview of the mediation of cognitive danger mapping based on traditional place designations in belief narratives. Firstly, processes of cognitive mapping are observed, using the example of plague tradition, and further on, parallels are drawn with modern religious phenomena, such as spiritual mapping in Neo-Pentecostalism, which aims to identify places in the landscape where demons lie in wait for humans, as well as delimiting the movement trajectories of dangerous criminals by way of their narrative localisation with concrete place designations in the landscape. As a novel feature, the article focuses on narrative localisation phenomena in connection with mobile sources of danger, which are not related to concrete places. The author demonstrates the similarities in the evolution of cognitive danger maps in older legends (e.g. plague legends) and in modern media-influenced belief narrations about potential and real criminals. Also, the importance of such danger maps in selective information collection and remembering is discussed, as well as how it determines the re-narration and behaviour. The author concludes that, in addition to pragmatic causes of origin (an aid for safe moving in space), narrative danger maps have a securing function supporting the subjective feeling of coping. 